\title{
The strategies of guidance and counseling teachers to increasing students' moral awareness in senior high school
}

\author{
Retno Purwasih $^{\left.1^{*}\right)}$, Sigit Sanyata ${ }^{1}$, Heri Retnawati ${ }^{1}$ \\ ${ }^{1}$ Universitas Negeri Yogyakarta, Indonesia \\ *)Corresponding author, Ðe-mail: retnopurwasih1224@gmail.com
}

\begin{abstract}
Moral awareness is a condition where the individual understands and comprehends the actions taken, both in the past, present, and future and realizes how the impact of behavior carried out both for oneself, others, and the surrounding. The purpose of this study is to find out how is the strategies of guidance and counseling teacher to increasing the moral awareness of students so far. This research is a qualitative type of phenomenology research. The data were collected through observation and interviews. The participants of the interviews were guidance and counseling teachers who teach in high schools which were chosen randomly. The data which were obtained from interviews were analyzed using the Miles \& Huberman qualitative research model. The results showed the guidance and counseling teachers' strategies in increasing moral awareness mostly through group guidance, group counseling, individual counseling, and responsive services with lecturing method, discussion, short film, and modeling.
\end{abstract}

Keywords: High school students, guidance and counseling teachers, moral awareness, descriptive qualitative.

How to Cite: Purwasih, R. (2020). The strategies of guidance and counseling teachers to increasing students' moral awareness in senior high school. COUNS-EDU: The International Journal of Counseling and Education, 5(4). 163-172. DOI: http://dx.doi.org/10.23916/0020200524740

This is an open access article distributed under the Creative Commons Attribution License, which permits unrestricted use, distribution, and reproduction in any medium, provided the original work is properly cited. (C2020 by author.

\section{Introduction}

The expanding time and technology has had a tremendous impact on the development of adolescent behavior today. Not only in adolescent behavior, according to Retnawati, Hadi, \& Nugraha (2016) education also experienced rapid development along with the development of civilization, knowledge, and technology. Although in the education process, learning about moral behavior has been applied to adolescents at school and at home, there are still many teenagers who behave immorally. Wiid, Cant, \& Niekerk (2013) stated that morality has become the foundation of all individuals' lives and their consciences and; in a way, morality is in sync with ethics. Borade (2012) moral refers to the behavior adopted from the environment and a set of rules that are agreed to be true or false. Sonnentag, McManus, Wadian, \& Saucier (2018) give examples of behavior that is immoral, for example stealing goods or money, cheating during exams, driving a vehicle while drunk, and so on. Immoral behavior that appears in individuals is more or less influenced by moral awareness (Wurtmann, 2017). Ishak \& Hussain (2012) mentioned that men and women have different levels of moral awareness and cognitive moral. In addition, Sturm (2017) highlighted that the process of decision making for each individual was affected by their own moral variables.

According to Rest (1986) moral awareness is one component in the cognitive model of ethical decision making processes which include recognizing moral problems, making moral judgments, establishing moral intentions or moral motivation, and engaging in moral behavior. Martinez \& Jaeger (2015) stated that moral awareness becomes a very important thing in making a moral decision. Events 
that occur around us often require consideration in order to bring out the right behavior. With the existence of moral awareness the individual realizes and understands what actions needed to be taken. Bertens (2013) mentioned that moral awareness is also called a conscience, which work within oneself that makes humans aware of what is morally good and what is morally bad in their behavior, hence moral awareness determine human's actions in their life. Bertens, Bessemans (2011) also said that moral awareness is as equal as conscience, where conscience and truth are not moral beliefs, however, moral awareness and self-criticism in the form of regret, liberation / approval, which refers to the behavior of the individual in the past, at the moment, and a temporary plan.

Baker (2014) considered moral awareness to be an indispensable ability to take morally right action even when there are influences from groups. Wurtmann (2017) informed that any situation or event could be considered in a moral point of view which is also called moral awareness. Gils (2014) stated that moral awareness of a person form after the occurrence of moral attention. As a social beings that lives with the large community, it is necessary to have a high moral awareness in order to avoid any morally wrong behavior among society. Kohlberg (1981) mentioned that individuals who have a high moral awareness tend to consider any situation within the scope of moral aspects before turning the thoughts into actions that lead to a better behavior or ethically correct. According to Ishak \& Hussain (2012) it is necessary to rise a higher level of moral awareness to the point of post-conventional moral awareness. With a higher level of moral awareness, a well morally right behavior will be created.

The phenomenon that often occurs today could be seen by the behavior of students or teenagers who tend to show a low level of moral awareness. Many adolescents behave morally impropriate such as stealing, fighting the teachers, committing acts of violence, drinking alcohol, consuming drugs, and others. Sukendar, Usman, \& West Java (2019) said that students currently have low level of honesty. According to Baker (2014) behavior that appears in adolescents or students is influenced much by their social environment such as the experience from the group they're hanging out with. The improper behavior was done without considering the impact on themselves, others, or the impact to the environment. This is a challenge for teachers in schools, especially counseling guidance teachers. Biocalti, Palareti \& Mameli (2017) stated that counseling services is a form of prevention. Therefore, with appropriate guidance and counseling services the students are expected to not behave morally wrong in the first place. One of the way is through inducing moral awareness.

The survey was conducted through interviews with several school guidance and counseling teachers regarding the effort to raise moral awareness. The results of the survey showed that the strategies carried out by guidance and counseling teachers is through the lecturing methods in the classroom, teaching empathy, and giving examples of role models, so far. The use of media was adjustable, for example by using video and showing daily life activities. It is also carried out through individual counseling services. Biocalti, Palareti \& Mameli (2017) said, the best strategy in counseling guidance services is discussion. Guidance and counseling services can not be separated from education, in its implementation the guidance and counseling teacher need to be professional, Retnawati, et al (2018) stated that the quality of education is not only determined by the plan and development of education itself but also the quality in implementing it. Likewise with the implementation of guidance and counseling services on students to induce the raise of moral awareness.

Zurqoni, Herawati, Arlinwibowo, \& Apino (2018) education has an important role in shaping human resources including the quality of students. Moral awareness could be induced through pedagogical or educational support (Fedorovna, 2015). According to Ishak, \& Hussain (2012) Moral awareness can be increased through learning along with the appropriate approach. Schools become the right place to introduce and strengthen moral awareness in students who are in their teenage phase. O'Connor \& Coyne (2017) mentioned that the adolescent stage in school years is a critical growth period with psychosocial challenges and undeniable development. Next is O'Connor \& Coyne that stated usually every school has a counselor staff who has various qualifications and provides various services in order to provide counseling to students. Biocalti, Palareti \& Mameli (2017) schools could be an ideal setting to limit or deal with youth problem. With the existence of counselor staffs, school becomes a facility to form moral awareness among students or adolescents to not behave morally bad. But then Biocalti, Palareti, \& Mameli also stated that so far students or adolescents are often reluctant to meet or seek help from counselors. 
Students have different abilities and different levels of moral awareness. To get the expected results according to objectives, the proper strategy is needed in the process of educating. This research was conducted to find out how the teacher's guidance and counseling strategies in an effort to increase the moral awareness of students to become better behaved human being.

\section{Method}

This study is a qualitative with phenomenology type research. The phenomenon that will be revealed is the strategies of guidance and counseling teachers to increase students' moral awareness. The data were collected through interviews and observations. The interviews were carried out with guidance and counseling teachers who taught at the Junior High School. The interview of the materials are how the teacher's guidance and counseling strategy has improved the moral awareness of the students, the obstacles they face, and the results they obtained. In addition to interviews, observations related to moral awareness are also conducted by researchers to see firsthand how the current level of moral awareness that the students have. The subject of this study are guidance and counseling teachers who have taught for at least 3 months. These participants were chosen randomly in a number of State High Schools in the Sleman region which consisted of 15 people. To the guidance and counseling teacher who was a participant, the researcher said that interviews and observations were carried out only for research purposes. All data related to the teacher is coded and kept secretly. The researcher also said that the results of the observation did not affect anything. The data was analyzed quantitatively and qualitatively. The quantitative analysis was done by calculating the percentage of teachers' performances on guidance services to raise moral awareness.

The reason teachers provide guidance and counseling services is to raise students' moral awareness. The following obstacles, strategies and also the use of observations made by researchers regarding teacher guidance and counseling strategies to increase the moral awareness are carried out with the qualitative research model of Miles \& Huberman. Miles and Huberman's (1994) model divides qualitative research into several steps, namely data collection, data reduction, data presentation, and drawing conclusions or data verification.

Based on the steps above, this research was carried out through these following stages: (1) collecting data by recording all phenomena that occur through interviews with guidance and counseling teachers in high schools; (2) reviewing the notes of the interview results by compiling the data that is considered important and not important, this stage is done repeatedly to check the possibility of errors in classifying them; (3) describing the data that has been classified according to the purpose of the study; and (4) make a final analysis in the form of research articles.

\section{Results and Discussions}

The results of the data analysis were classified into 5 topics. The topics are: (1) the urgency of moral awareness for students; (2) strategies and results in teaching moral awareness to students; (3) changes and applications of services in daily life for students; (4) student responses and ways to measure student understanding; and (5) obstacles and strategies in providing services regarding moral awareness. The results of data analysis for each topic could be seen in these following paragraphs.

\section{The urgency of students' moral awareness}

Moral awareness is generally very important for everyone to have, including High School students. All guidance and counseling teachers say that moral awareness is very important to be owned and taught to students in schools so that students can behave properly in accordance with the existing morals. The details of the interview results are presented in table 1 . 
Table 1. The Urgency of Students' Moral Awareness

\begin{tabular}{ll}
\hline Sub Theme & $\begin{array}{l}\text { Relations between Sub Conclusions } \\
\text { Theme }\end{array}$ \\
$\begin{array}{l}\text { Very important, in order for students to All guidance and the moral awareness is very } \\
\text { support good character }\end{array}$ \\
$\begin{array}{l}\text { Important, in order to students to support } \\
\text { agreed that the moral students to have morally right } \\
\text { good character }\end{array}$ \\
$\begin{array}{l}\text { The most important, in order to students } \\
\text { important to teach in } \\
\text { to behave properly }\end{array}$ \\
$\begin{array}{l}\text { Important, in order to students to behave } \\
\text { behave morally right. }\end{array}$ \\
$\begin{array}{l}\text { Verally right. } \\
\text { behave mortant, in order to students to }\end{array}$ \\
Important, in order to students act politely
\end{tabular}

The results in table 1 also show that moral awareness is taught to students to in order to have morally right behavior, to form good character, and to have good manners while behaving and speaking.

\section{Strategies and outcomes in teaching moral awareness to students}

Guidance and counseling teachers at school provides the material on moral awareness in various ways. Almost all of the services available in guidance and counseling could be used to teach moral awareness to students. The guidance and counseling teacher chooses the most effective to use. Apart from using various services such as classical services, group guidance, group counseling, individual counseling, and responsive services, teaching moral awareness to students also uses various methods so that students can easily accept and understand them, namely modeling, question and answer, and discussion. The results of using these services and methods are quite effective for students. Not all of the students immediately understand and comprehend the material presented because it depends on the ability of each student, but generally the results obtained are quite good. The details of the analysis can be seen in table 2 .

Table 2. Strategies used to increase moral awareness and outcomes

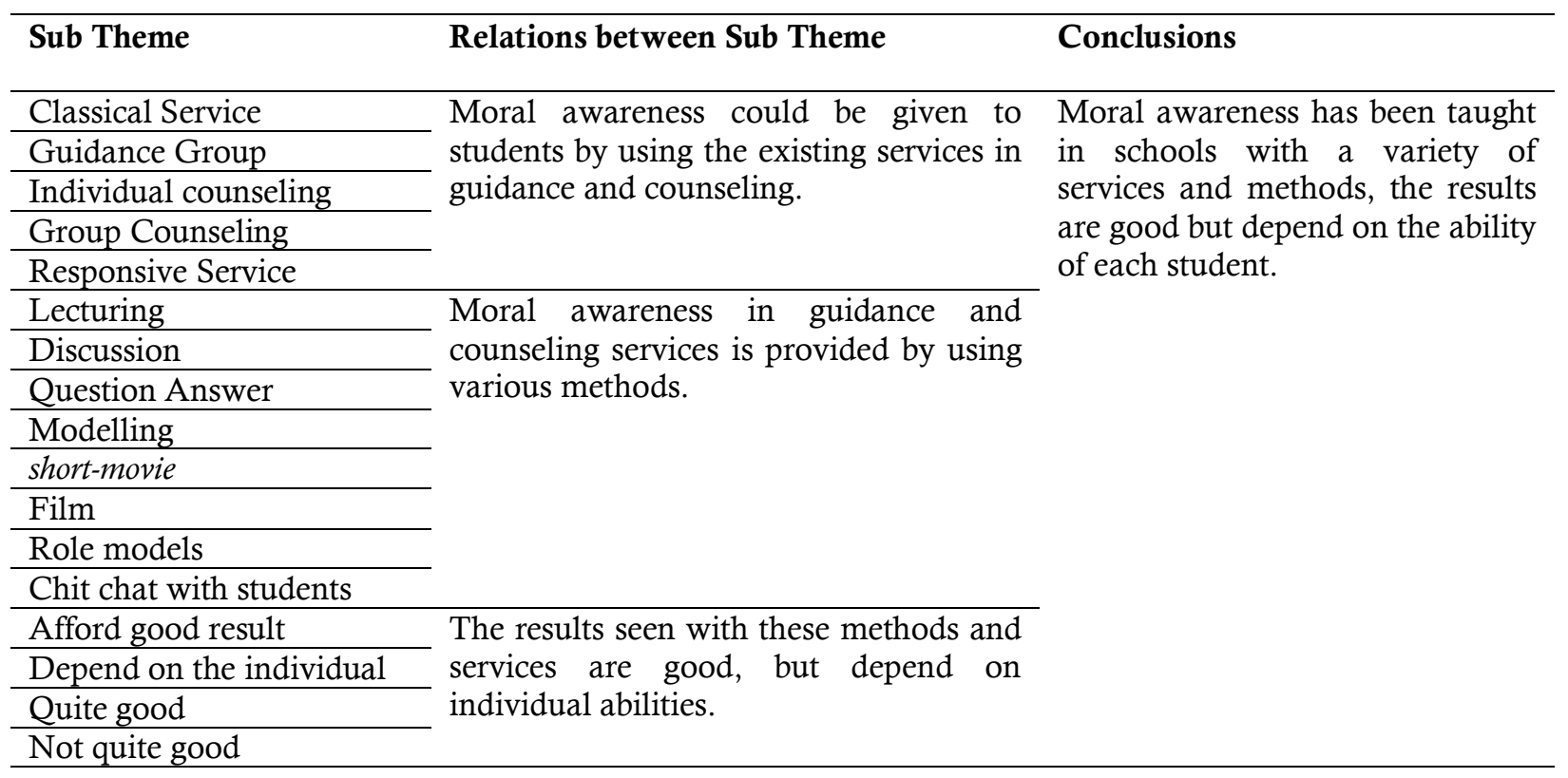

The results of providing material with services and methods according to the table above are good. But not all of the students get good results. The ability to receive an individual material is different. The level of attention is different, there are students who really pay attention but some other are not interested in paying attention. The services used are adjusted to the students characters. Even though guidance and counseling teachers have provided the material through classical services but there are still some students 
who have improper behavior, those students will be called and given the group guidance services or group counseling about moral awareness hence, it is expected that they will not repeat their morally wrong behaviour.

\section{Changes and applications in students' daily life}

The students after being given the services regarding moral awareness do not immediately change. There are students who are aware of their improper behavior, hence change for the better due to their moral awareness. However, some others do not change. Some changes could be seen in ways of speaking. They will be more polite, behave more properly, can control themselves while emotional encounter, students become more respectful and appreciative toward the teacher. Some of these changes apply every day but some are not. The results of the data specifications are presented in table 3 .

Table 3. Changes and Applications in Students' Daily Life

\begin{tabular}{|c|c|c|}
\hline Sub Theme & $\begin{array}{l}\text { Relations between Sub } \\
\text { Theme }\end{array}$ & Conclusions \\
\hline $\begin{array}{l}\text { There are changes in behaviour, but not } \\
\text { yet consistent. Sometimes they behave } \\
\text { improperly }\end{array}$ & \multirow{6}{*}{$\begin{array}{l}\text { After the moral } \\
\text { awareness materials } \\
\text { given, students behave } \\
\text { better than before even if } \\
\text { the changes do not } \\
\text { directly seen. }\end{array}$} & \multirow{11}{*}{$\begin{array}{l}\text { After the moral awareness } \\
\text { materials given, students behave } \\
\text { better than before, even though } \\
\text { not all of the students reflect the } \\
\text { services in their daily life. }\end{array}$} \\
\hline $\begin{array}{l}\text { The way of students' talk and utterance } \\
\text { are more polite to the teacher }\end{array}$ & & \\
\hline $\begin{array}{l}\text { Some of the students are able to control } \\
\text { their emotion in certain situations }\end{array}$ & & \\
\hline $\begin{array}{l}\text { The changes can't be seen directly, for } \\
\text { some time there are some who show their } \\
\text { changes }\end{array}$ & & \\
\hline $\begin{array}{l}\text { Students behave more polite in front of } \\
\text { their teachers and friends. }\end{array}$ & & \\
\hline $\begin{array}{l}\text { Students become more polite with their } \\
\text { teachers }\end{array}$ & & \\
\hline $\begin{array}{l}\text { Some students reflect the services in their } \\
\text { daily life }\end{array}$ & \multirow{5}{*}{$\begin{array}{l}\text { Not all of the students } \\
\text { who reflect the services in } \\
\text { their daily life. }\end{array}$} & \\
\hline $\begin{array}{l}\text { There are students who do not reflect the } \\
\text { services in their daily life }\end{array}$ & & \\
\hline $\begin{array}{l}\text { Students reflect the services only when the } \\
\text { teacher's around }\end{array}$ & & \\
\hline $\begin{array}{l}\text { There are students who do not care about } \\
\text { the moral awareness and did not apply it } \\
\text { at all }\end{array}$ & & \\
\hline $\begin{array}{l}\text { The students do not always apply in their } \\
\text { daily life }\end{array}$ & & \\
\hline
\end{tabular}

In general, giving material about moral awareness through guidance and counseling has succeeded in making a change in student behavior. Initial behavior that is not morally appropriate, such as speaking disrespectfully, behaving poorly, etc., becomes more controlled and diminished. Although not all students immediately change and apply it in everyday life, the material on moral awareness increases students' knowledge about morals and good behavior.

Student response when given moral awareness materials

The results of data analysis regarding students' responses when the guidance and counseling teacher provided the moral awareness material is presented in table 4 . The results showed that not all students responded well when given counseling guidance services regarding moral awareness. The following table showed student responses: 
Table 4. Student Responses when Given Moral Awareness Material

\begin{tabular}{|c|c|c|}
\hline Sub Theme & $\begin{array}{l}\text { Relations between Sub } \\
\text { Theme }\end{array}$ & Conclusions \\
\hline $\begin{array}{l}\text { Students are enthusiast following the } \\
\text { service }\end{array}$ & \multirow{6}{*}{$\begin{array}{l}\text { Most students respond } \\
\text { and enthusiastically } \\
\text { attend services with the } \\
\text { theme of moral } \\
\text { awareness, but some are } \\
\text { not enthusiastic. }\end{array}$} & \multirow{11}{*}{$\begin{array}{l}\text { Not all students respond and have } \\
\text { a high enthusiasm in following } \\
\text { services regarding moral } \\
\text { awareness, it is also seen from the } \\
\text { teacher's assessment of guidance } \\
\text { and counseling conducted by way } \\
\text { of assignments, post-tests, } \\
\text { questions, and observations. }\end{array}$} \\
\hline Students listen carefully & & \\
\hline The students realize the wrongdoing & & \\
\hline Students respond very well & & \\
\hline Some students are not enthusiast & & \\
\hline Some students are avoiding and betitling & & \\
\hline The teacher gives tasks to students & \multirow{5}{*}{$\begin{array}{l}\text { To see the level of } \\
\text { student understanding, } \\
\text { the teacher evaluates in } \\
\text { several ways such as } \\
\text { assignments, post-tests, } \\
\text { questions, normative and } \\
\text { observations. }\end{array}$} & \\
\hline $\begin{array}{l}\text { The teacher gives reflective questions } \\
\text { toward the students }\end{array}$ & & \\
\hline $\begin{array}{l}\text { The teacher gives the post-test about the } \\
\text { materials toward the students }\end{array}$ & & \\
\hline $\begin{array}{l}\text { The teacher observes the students in } \\
\text { school }\end{array}$ & & \\
\hline $\begin{array}{l}\text { The teacher do evaluation normatively to } \\
\text { students }\end{array}$ & & \\
\hline
\end{tabular}

From the table above it can be seen that some students respond enthusiastically in following guidance and counseling services regarding moral awareness, but some are not enthusiastic. This can be caused by the way the guidance and counseling teacher delivers the material. On the other hand students' interest and awareness affect how to respond to the material given. Teacher guidance and counseling after providing material on moral awareness usually measures or evaluates students' understanding of the material presented. The way teachers do guidance and counseling also varies, including by giving assignments to students, giving reflection questions to students at that time, giving post-tests, observing behavior while at school, and conducting normative evaluations to students. Those steps are done to gain the understanding and level of moral awareness of students and their application in their daily lives at school and outside of the school environment.

Obstacles and strategies of guidance and counseling teacher in increasing student moral awareness There are many obstacles faced by the teacher of guidance and counseling in their service practice in schools. The biggest obstacle faced is the lack of scheduled class hours at because of the assumption that guidance and counseling is less important to students than other subjects. But the guidance and counseling teacher still has a strategy in providing services to students, including by using class hours that are currently empty or if it is very important to enter the classroom, guidance and counseling teachers ask for other subject hours to provide classical services to students. The data are presented in the following table 5.

The absence of scheduled class hours makes teacher guidance and counseling hard to provide classical services to students in the classroom. The principal considers that guidance and counseling is less important to be given the class hours. However, from the results of the interview, the headmaster gave the teacher guidance and counseling to take any hours of class time when it was very necessary to provide classical services to students. In addition, guidance and counseling teachers will use empty class hours to enter the classroom. This kind of obstacles not only make it difficult to provide classical services but will also affect the making of guidance and counseling programs in schools.

Guidance and counseling Teacher does not make these obstacles as an excuse for not providing services to students. There are many other ways to provide services to students regarding moral awareness, such as group guidance, group and individual counseling, and responsive services. That way students still get guidance and counseling services well. There are some guidance and counseling teachers who have their own way of providing services to students, such as by approaching students personally. During the break the guidance and counseling teacher will go around to classes to talk with students and put moral values on students. That way, students will feel closer to the teacher and easier in accepting the material delivered through informal conversations. 
Moral awareness is influenced from several factors, according to Reynolds (2006) factors that influence moral awareness are the existence of damage, violation of behavioral norms, utilitarianism, formalism, and the state of danger/loss. Damage can foster moral awareness, with the damage the individual realizes that this is not good and harms themselves resulting in their moral awareness. The same thing happens when there is a violation of the norms of behavior, when individuals think that the behavior does not comply with applicable rules, moral awareness arises to direct their behavior toward the existing rules. The next factor is utilitarianism, which is the way of thinking of humans in acting or behaving focused on the goals and based on consideration in order to create a good. Utilitarianism makes individuals always lead to good behavior that thinks of benefits for others and the environment. Formalism according to Bradi's cited in (Reynolds, 2006) is as a reference to determine moral behavior based on obligations. In general, formalism emphasizes the importance of patterns and rules of behavior or some formal ethical features that determine the situation or decision. The last factor, a dangerous state or loss, with the existence of a dangerous state or loss of moral awareness of individuals will grow. Basically, moral awareness leads to doing good deeds that are beneficial to others and the environment, when there is a danger or a loss that felt as unpleasant thing then the individual will think with awareness of how to avoid these circumstances.

Table 5. Obstacles and Strategies of Guidance and Counseling Teacher

\begin{tabular}{|c|c|c|}
\hline Sub Theme & $\begin{array}{l}\text { Relations between Sub } \\
\text { Theme }\end{array}$ & Conclusions \\
\hline No schedule for the classrooms & \multirow{5}{*}{$\begin{array}{l}\text { Almost all of the biggest } \\
\text { obstacle faced by } \\
\text { Guidance and counseling } \\
\text { teacher is no scheduled } \\
\text { classroom, because it is } \\
\text { assumed to be less } \\
\text { important. }\end{array}$} & \multirow{12}{*}{$\begin{array}{l}\text { Almost all of the biggest obstacle } \\
\text { faced by Guidance and } \\
\text { counseling teacher is no } \\
\text { scheduled classroom, so that the } \\
\text { service given are only outside of } \\
\text { the classroom, however in any } \\
\text { emergency situation, Guidance } \\
\text { and counseling teacher is asking } \\
\text { for another subject hours }\end{array}$} \\
\hline $\begin{array}{l}\text { Students' factor who refuse to be given the } \\
\text { guidance and counseling }\end{array}$ & & \\
\hline $\begin{array}{l}\text { Guidance and counseling is assumed to be } \\
\text { less important by the headmaster and } \\
\text { other teachers }\end{array}$ & & \\
\hline $\begin{array}{l}\text { Inadequate Guidance and counseling } \\
\text { room }\end{array}$ & & \\
\hline $\begin{array}{l}\text { The headmaster do not aware the roles } \\
\text { and functions of Guidance and } \\
\text { Counseling }\end{array}$ & & \\
\hline $\begin{array}{l}\text { Guidance and counseling teachers filling } \\
\text { up the empty hours when the scheduled } \\
\text { teacher do not attend }\end{array}$ & \multirow{7}{*}{$\begin{array}{l}\text { Guidance and } \\
\text { counseling teachers use } \\
\text { empty hours or another } \\
\text { subject's hours to give } \\
\text { classical services in the } \\
\text { classroom, and give } \\
\text { understanding to the } \\
\text { headmaster as expected } \\
\text { to let them have } \\
\text { scheduled classroom }\end{array}$} & \\
\hline $\begin{array}{l}\text { The Guidance and counseling teacher are } \\
\text { using sports and ICT hours }\end{array}$ & & \\
\hline $\begin{array}{l}\text { Calling students directly to Guidance and } \\
\text { counseling room to be given the } \\
\text { Guidance and counseling services }\end{array}$ & & \\
\hline $\begin{array}{l}\text { Asking for another subject hours if it is } \\
\text { tremendously urgent to be given the } \\
\text { classical services }\end{array}$ & & \\
\hline $\begin{array}{l}\text { Personal approach to students to get closer } \\
\text { to them }\end{array}$ & & \\
\hline $\begin{array}{l}\text { Walking around in break hours to interact } \\
\text { with students in order to know their } \\
\text { activity and get closer with them }\end{array}$ & & \\
\hline $\begin{array}{l}\text { Giving understanding to the headmaster } \\
\text { about the roles and function of Guidance } \\
\text { and counseling. It is hoped to give } \\
\text { Guidance and counseling scheduled } \\
\text { classroom }\end{array}$ & & \\
\hline
\end{tabular}


The many factors that influence moral awareness make the level of moral awareness of each individual different. The results showed that moral awareness is very important to be taught and improved in high school students so that students have good character and showing morally right behaviour. Magnis Suseno in Wahana (2016) explained there are two levels of moral awareness of individuals namely autonomous and heteronomous. Judging from the results of the study showed that the level of moral awareness of high school students is at a heteronomous level, meaning that the state of someone doing good or having proper behavior are due to pressure, fear of being punished by the teacher, forced, etc. It is not because of an awareness of the obligations that must be fulfilled. In contrast to the level of heteronomous moral awareness, autonomous morals make individuals behave and act because the awareness comes from within themselves to act according to the existence moral values.

Students who have high moral awareness will behave properly in accordance with applicable morals. This statement is in supported with the opinion of Reynolds \& Miller (2015) which said that someone with good moral awareness is able to realize that all situations have moral content and can be considered from a morally right point of view. That way, individuals will choose the behavior that will be done by considering the behavior is good or not. In the community and school environment, it is important to behave properly in accordance with applicable morals, but the behavior should be carried out from within the individual himself.

Moral awareness can be taught through guidance and counseling services in schools. Fedorovna (2015) stated that moral awareness of students can be formed through education. The strategies used various methods. The services used can be in the form of classical services, group guidance, group counseling, individual counseling, and responsive services. However, the obstacle is that guidance and counseling do not have scheduled class hours at school so they cannot provide classical services optimally. Farozin (2019) mentioned that guidance and counseling services are often considered unimportant in schools and seen as secondary or optional. When guidance and counseling teachers cannot provide material on moral awareness through classical way, it can be done with group guidance services. In order for students to be interested in paying attention to the material presented, guidance and counseling teachers use methods such as using short film, modeling, role models, and others. Even so the results of student understanding are not all good. Students have their respective perceptions of something. Gok, Demirtas \& Arslan (2017) said everyone has a different reaction in a situation in the environment. Reynolds, Owens \& Rubenstein (2012) explained that each individual shows differences in giving attention to moral problems in experience and decisions. That way, when the guidance and counseling teacher gives material to students, the students' different responses are enthusiastic or not at all about paying attention to the teacher. This has an impact on the results obtained from students.

\section{Conclusions}

Efforts to increase moral awareness have been carried out by almost all guidance and counseling teachers in high schools. The goal is that students behave both in school and in the community in accordance with applicable morals. Moral awareness makes students able to consider what has been done, is being done, and will be done. The strategy used by the guidance and counseling teacher in increasing students' moral awareness is the existence services in guidance and counseling. These services are classical services, group guidance, group counseling, and individual counseling. The method used in these services also varies such as lectures, discussions, questions and answers, modeling, and screening films or short films. Using a variety of methods that can make students easier to accept the material about moral awareness provided.

On the other hand, there are obstacles that must be faced by the guidance and counseling teachers in providing services to students. The biggest obstacle is the absence of scheduled class hours at school, making it difficult to provide services classically. Facing existing obstacles, guidance and counseling teachers have other strategies to continue providing services to students. Among them through group guidance services or group counseling. The implementation was carried out in the guidance and counseling room that was available. For students who still have low awareness which is shown by poorly behavior, guidance and counseling teachers provide special services for them namely individual counseling, so it is more effective to induce moral awareness in these students. However, to achieve better 
results, guidance and counseling is expected to get a scheduled class hours to provide classical services to students.

\section{References}

Baker, D. F. (2014). When Moral Awareness Isn't Enough: Teaching Our Student To Recognize Social Influence. Journal Of Management Education,38(4),511-532. DOI:10.1177/1052562913504922.

Bertens, K. (2013). Etika. Yogyakarta: Kanisius.

Bessemant, C. (2011). Moral Conflicts and Moral Awareness. Journals Cambridge, 86(4), 536-587. DOI: 10.1017/S0031819111000362

Biolcati, R., Palareti, L., Mameli, C. (2018). What Adolescents Seeking Help Teach us About a SchoolBased Counseling Service. Child Adolesc Soc Work Journals, 35, 45-56. DOI $10.1007 /$ s10560-0170503-7.

Borade, G. (2012). Difference between ethics and morality. Retrieved from: http://www.buzzle.com/articles/difference-between-ethics-and-morality.html.

Farozin, M. (2019). Counselor Professional Identity of Counselor Profession Education. Journals Cakrawala Pendidikan, 38(1). doi: 10.21831/cp.v38i1.22515.

Ferodovna, K. A. (2015). Pedagogical Support of Formation of Moral Awareness of Students. Education and Science, 6(125). DOI: 10.17853 / 1994-5639-2015-6-143-153.015-2714-1.

Gils, S, V., Quaquebeke, N., van Knippenberg, D., van Dijke M. \& de Cremer, D. (2014). Ethical leadership and follower organizational deviance: The moderating role of follower moral attentiveness. The Leadership Quarterly, doi.10.1016/j.leaqua.2014.08.005

Gok, K., Demirtas, O.,\& Arslan, A. (2017). The Moderating Effects of Moral Awareness and Moral Attentiveness on the Relationship between Ethical Leadership and Workplace Deviance. Retrieved from https://www.researchgate.net/publication/322012038.

Ishak, S., \& Hussain, M. Y. (2012). Moral awareness among future development agents: an action study. Asian Journal of Business Ethics, 2(1), 79-89. doi:10.1007/s13520-012-0018-4.

Kohlberg, L. (1981). The philosophy of moral development. San Francisco: Harper \& Row.

Martinez, L. F., \& Jaeger, D. S. 2015. Ethical Decision Making In Counterfeit Purchase Situation: The Influence Of Moral Awareness And Moral Emotions On Moral Judgement And Purchase Intentions. Journal of Consumer Marketing, (33)3, 213-223. DOI 10.1108/JCM-04-2015-1394.

Miles, M. B., \& Huberman, M. A. (1994). Qualitative data analysis: an expanded sourcebook (2rd ed). London: Sage Publication.

O'Connor. M., \& Coyne. J (2017). School-Based Counselling Service Use: A Year in the Life of a School Counselling Department. Journal of Psychologists and Counsellors in Schools, 27(2), 251-261. doi 10.1017/jgc.2016.30.

Rest, J. R. (1986). Moral development: Advances in research and theory. New York: Praeger

Retnawati, H., Hadi, S., \& Nugraha, A, C. (2016). Vocational High School Teachers' Difficulties in Implementing the Assessment in Curriculum 2013 in Yogyakarta Province of Indonesia. International Journal of Instruction, 9(1). e-ISSN: 1308-1470.

Retnawati, H., Djidu, H., Kartianom, Apino, E., Anazifa, R, D., (2018). Teachers' Knowledge About Higher-Order Thinking Skills And Its Learning Strategy. Problems Of Education In The $21^{\text {st }}$ century, 76(2), 215. ISSN 1822-7864 (Print) ISSN 2538-7111 (Online).

Reynolds, S, J. (2006). Moral Awareness and Ethical Predispositions: Investigating the Role of Individual Differences in the Recognition of Moral Issues. Journal of Applied Psychology, 91(1), 233243. DOI: $10.1037 / 0021-\quad 9010.91 .1 .233$.

Reynolds,S. J., Owens, B. P., \& Rubenstein, A. L. (2012). Moral stress: Considering the nature and effects of managerial moral uncertainty. Journal of Business Ethics, 106, 491-502.

Reynolds, S. J., \& Miller, J. A. (2015). The recognition of moral issues: moral awareness, moral sensitivity and moral attentiveness. Current Opinion in Psychology, 6, 114-117. doi:10.1016/j.copsyc.2015.07.007

Sonnentag, T. L., McManus, J. L., Wadian, T. W., \& Saucier, D. A. (2018). Prioritizing Morality In The Self And Consistent Moral Responses Despite Encouragement To Behave Immorally. Journal of Moral Education, 111. doi:10.1080/03057240.2018.1469479.

Sturm, R, E. (2017). Decreasing Unethical Decisions: The Role of Morality-Based Individual Differences. Journals Bussnises Ethics, 142: 37-57. DOI 10.1007/s10551-015-2787-X. 
Sukendar, A., Usman, H., \& Jabar, C, S, A. (2019). Teaching-Loving-Caring (Asah-Asih-Asuh) And Semi-Military Education On Character Education Management. Journals Cakrawala Pendidikan,38(2). doi: $10.21831 /$ cp.v38i2.24452.

Wiid, J, A., Cant, M, C..\& Niekerk, C, V. (2013). Moral Behavior and Ethical Misconduct in Nigerian Small Businesses. International Busines \& Economic Research Journal, 12(9). Retrieved:https://www.clutejournals.com/index.php/IBER/article/download/8054/8108.

Wurtmann, K. (2017). Implicit Theories and Issue Characteristics as Determinants of Moral Awareness and Intentions. Journals Bussniss Ethics, 142, 93-116. DOI:10.1007/s10551.

Zurqoni, Z., Retnawati, H., Arlinwibowo, J., \& Apino, E. (2018). Stategy an Implementation of character education in senior high schools and vocational high schools. Journal of Social Studies Education Research, 370-379, 9(3). Retrieved from https://dergipark.org.tr/en/download/articlefile/661109. 